\title{
Effects of artificial sweeteners on glucagon-like peptide 1 secretion in GLUTag cells, an in vitro model of enteroendocrine cells
}

\author{
K. Mehat and C. Corpe \\ Division of Diabetes and Nutritional Sciences, King's College London, SE1 9NH, UK.
}

The effects of artificial sweeteners (AS) on the peptide hormone-producing enteroendocrine cells (EEC) of the gastrointestinal tract are controversial (contradictory studies in humans, animals and cells) ${ }^{(1)}$. Recently, sucralose, a highly potent AS, has been shown to induce secretion of the insulin regulating and blood glucose lowering hormone, glucagon-like peptide 1 (GLP-1), from intestinal in vitro models ${ }^{(2)}$. It is suggested that it may be interacting with the sweet taste-receptors found on EECs ${ }^{(3)}$. However the effects of other commonly used AS in the UK, such as aspartame, acesulfame-k and Canderel ${ }^{\circledR}(1.4 \%$ aspartame; $0.95 \%$ acesulfame-k) have not been investigated. The aim of the present study was to assess the effects of these AS on GLP-1 secretion in GLUTag cells (mouse EEC line).

GLUTag cells were incubated with test reagents for 2 hours at $37^{\circ} \mathrm{C}$ and the supernatant collected. GLP-1 was measured from the supernatant using a GLP-1 (Active) ELISA assay (EMD Millipore ${ }^{\circledR}$, UK). Data is presented as means and standard deviation.

At dietary relevant doses $(0.25-5 \mathrm{mM})$ the individual AS, aspartame and acesulfame-k, and the AS mixture, Canderel ${ }^{\circledR}$ significantly induced GLP-1 secretion in GLUTag cells when compared to baseline (except for $0.25 \mathrm{mM}$ acesulfame-k) and values were similar to glucose-induced GLP-1 secretion (table 1). Cells incubated in a combination of Canderel ${ }^{\circledR}$ and glucose $(0.4 \mathrm{mM}$ and $5 \mathrm{mM})$ showed the highest secretion of GLP-1 (table 1); indicating a potential synergistic effect of AS and other nutrients in EEC function. In conclusion, our in vitro data suggests certain AS given alone and in combination with glucose may result in a GLP-1 response.

Table 1. Values are means ( $\mathrm{n}=6$; different passage numbers). Mean values were significantly different compared to baseline (ANOVA* or Student's T test $\square$ ); ${ }^{*} \square \mathrm{P}<0.05$; a: Canderel $^{\circledR}$ dose $=0.4 \mathrm{mM}$ aspartame and $0.4 \mathrm{mM}$ acesulfame- $\mathrm{k}$.

\begin{tabular}{|c|c|c|c|c|c|c|c|c|c|c|c|c|}
\hline \multirow{2}{*}{$\begin{array}{l}\text { Test Reagents } \\
\mathrm{mM}\end{array}$} & \multicolumn{2}{|c|}{$\begin{array}{l}\text { Glucose } \\
\text { GLP-1(pM) }\end{array}$} & \multicolumn{2}{|c|}{$\begin{array}{l}\text { Aspartame } \\
\text { GLP-1(pM) }\end{array}$} & \multicolumn{2}{|c|}{$\begin{array}{l}\text { Acesulfame-K } \\
\text { GLP-1(pM) }\end{array}$} & \multicolumn{2}{|c|}{$\begin{array}{l}\text { Canderel }^{\circledR a} \\
\text { GLP-1 }(\mathrm{pM})\end{array}$} & \multicolumn{2}{|c|}{$\begin{array}{l}\text { Canderel }^{(\mathbb{a} a}+0.4 \\
\text { mM Glucose } \\
\text { GLP-1 }(\mathrm{pM})\end{array}$} & \multicolumn{2}{|c|}{$\begin{array}{l}\text { Canderel }^{\text {Ra }}+5 \\
\text { mM Glucose } \\
\text { GLP-1(pM) }\end{array}$} \\
\hline & Mean & SD & Mean & $\mathrm{SD}$ & Mean & SD & Mean & SD & Mean & $\mathrm{SD}$ & Mean & $\overline{\mathrm{SD}}$ \\
\hline 0 (baseline) & 86 & 13 & 86 & 13 & 86 & 13 & 86 & 13 & 86 & 13 & 86 & 13 \\
\hline 0.25 & $123^{*}$ & 16 & $113^{*}$ & 13 & 92 & 15 & & - & & - & & - \\
\hline 0.4 & $134 *$ & 17 & $102 *$ & 18 & $131^{*}$ & 18 & $122 \square$ & 8 & $180 \square$ & 42 & $203 \square$ & 43 \\
\hline 2.5 & $165^{*}$ & 35 & $142 *$ & 15 & $116^{*}$ & 12 & & - & & - & & - \\
\hline 5 & $145^{*}$ & 20 & $147^{*}$ & 36 & $119^{*}$ & 31 & & - & & - & & - \\
\hline
\end{tabular}

1. Steinert R, Frey F, Töpfer A et al. (2011) Br J Nutr 105, 1320-1328.

2. Margolskee R, Dyer J, Kokrashvili Z et al. (2007) Proc Natl Acad Sci 104, 15075-15080.

3. Jang H, Kokrashvili Z, Theodorakis M et al. (2007) Proc Natl Acad of Sci 104, 15069-15074. 